\title{
Stimulation of Monovalent Cation Active Transport by Low Concentrations of Cardiac Glycosides
}

\author{
ROLE OF CATECHOLAMINES
}

\author{
Thomas J. Hougen, NANCY SPICER, and Thomas W. SMith, Cardiovascular Division, \\ Brigham and Women's Hospital, Cardiology Department, Children's Hospital \\ Medical Center, Departments of Medicine and Pediatrics, Harvard Medical \\ School, Boston, Massachusetts 02115
}

\begin{abstract}
A B S T RAC T The stimulatory effect of low concentrations of ouabain on the Na-K pump in isolated guinea pig left atria was studied in vitro by assessing active transport of the $\mathrm{K}^{+}$analog $\mathbf{R b}^{+}$. Active transport of $\mathbf{R b}^{+}$ was stimulated $20 \pm 8 \%$ (SEM, $P<0.05$ ) above control values by $3 \mathrm{nM}$ ouabain, but was inhibited by concentrations $>10 \mathrm{nM}$. Preincubation with the $\beta$-adrenergic antagonist propranolol $(1 \mu \mathrm{M})$ completely blocked stimulation of active transport of $\mathrm{Rb}^{+}$by $3 \mathrm{nM}$ ouabain. Norepinephrine, $10 \mathrm{nM}$, increased $\mathrm{Rb}^{+}$active transport $29 \pm 10 \%(P<0.02)$ above control values. The $\beta$ adrenergic agonist 1-isoproterenol, $10 \mathrm{nM}$, increased active transport of $\mathrm{Rb}^{+}$by $33 \pm 10 \%(P<0.01)$ above control levels. This stimulatory effect was abolished if tissues were first exposed to propranolol. Tyramine $(0.1 \mu \mathrm{M})$, a stimulator of endogenous catecholamine release, increased active transport of $\mathrm{Rb}^{+} 26 \pm 12 \%$ $(P<0.05)$ above control values. $\mathrm{Rb}^{+}$active transport was not significantly changed when left atrial tissues were incubated with $\alpha$-adrenergic agonists or antagonists. Ouabain stimulation of $\mathrm{Rb}^{+}$active transport was prevented by in vivo depletion of myocardial endogenous catecholamines by either reserpine or 6-hydroxydopamine. These findings indicated that in myocardial tissue, $\mathrm{Na}-\mathrm{K}$ pump stimulation by low concentrations of ouabain is mediated at least in part through $\beta$-adrenergic effects of endogenous catecholamines.
\end{abstract}

\section{INTRODUCTION}

In 1963, Repke (1) proposed that the principal cellular mechanism of action of cardiac glycosides involved

Address correspondence to Dr. Hougen, Children's Hospital Medical Center, 300 Longwood Avenue, Boston, Mass. 02115.

Received for publication 24 March 1981 and in revised form 15 July 1981. inhibition of myocardial monovalent cation active transport mediated by sodium- and potassium-activated adenosine triphosphatase (NaK-ATPase). ${ }^{1}$ Since then, a vast literature has emerged dealing with inhibition of NaK-ATPase and monovalent cation active transport by cardiac glycosides $(2,3)$. Nevertheless, a number of investigators using a variety of tissues have shown apparent stimulation of monovalent cation active transport by low concentrations of cardiac glycosides in the nanomolar range (4-8), with inhibition at higher concentrations $(5,6)$. The mechanism underlying this biphasic effect remains unexplained.

Several lines of evidence have led us in the studies reported here to test the hypothesis that the apparent stimulation of the sodium pump by cardiac glycoside concentrations in the nanomolar range is mediated by endogenous catecholamines. First, it is well known that catecholamines can stimulate monovalent cation active transport in intact tissues via a $\beta$-adrenergically mediated effect $(9-11)$; activation of NaK-ATPase in cell membrane preparations has also been reported, and may involve effects not specifically dependent on $\beta$-adrenergic mechanisms (12). Second, intact myocardium contains substantial norepinephrine stores in adrenergic nerve terminals; these terminals contain an appreciable portion of the cardiac glycoside sensitive NaK-ATPase content of myocardium (13). Third, in isolated tissue or perfused organ preparations, ouabain promotes the release of endogenous norepinephrine (14-17) as well as inhibiting norepinephrine reuptake (14). In the studies described here, we demonstrate stimulation of monovalent cation active transport in guinea pig left atria by low ouabain concentrations in the nanomolar range and further demonstrate that this

\footnotetext{
${ }^{1}$ Abbreviations used in this paper: NaK ATPase, sodiumand potassium-activated adenosine triphosphatase; 6-OHDA, 6-hydroxydopamine.
} 
stimulatory effect is mediated by $\beta$-adrenergically mediated effects of endogenous catecholamines.

\section{METHODS}

Adult male albino guinea pigs (Hartley strain, Elm Hill Farms, Chelmsford, Mass.) weighing 250-300 g were stunned, their chests were opened, and their hearts were quickly excised. Left atria were dissected free in oxygenated physiologic media at room temperature. The atria were divided by scissors into three or four parts, each weighing 4-12 mg. The tissues were preincubated in oxygenated physiologic media for $15 \mathrm{~min}$ at room temperature and then transferred to flasks containing physiologic media saturated with $95 \% \mathrm{O}_{2}$, $5 \% \mathrm{CO}_{2}$ for incubation periods of $60-210 \mathrm{~min}$ at $30^{\circ} \mathrm{C}$. Physiologic media contained $\mathrm{NaCl}, 120 \mathrm{mM} ; \mathrm{KCl}, 4.0 \mathrm{mM} ; \mathrm{CaCl}_{2}$, $2.5 \mathrm{mM} ; \mathrm{NaHCO}_{3}, 24 \mathrm{mM} ; \mathrm{NaH}_{2} \mathrm{PO}_{4}, 1.1 \mathrm{mM} ; \mathrm{MgCl}_{2}, 2.0$ $\mathrm{mM}$; and glucose, $5.6 \mathrm{mM}$ (pH 7.4).

Details of protocols for individual experiments are described, together with results, in the section that follows. All solutions were made fresh daily. In a typical experiment, left atria from 15-20 animals were divided into three or four pieces and pooled. Six to eight pieces of tissue were then placed in flasks with composition of incubation media, as described in individual experiments. Experiments were repeated two or more times and transport values from each atrial sample were combined to determine the mean value given for each datum point (note $n$ value in figures). Initially we used incubation times of 60-210 min but found that the results at $210 \mathrm{~min}$ were generally similar to those of the shorter period. Reported here are the results of experiments using a 60-min incubation period.

Determinations of ${ }^{86} \mathrm{R} b^{+}$uptake. After incubation with various pharmacological agents for $30 \mathrm{~min}$, atrial samples were placed in identical media to which was added ${ }^{86} \mathbf{R b}^{+}$as ${ }^{86} \mathrm{RbCl}$ (New England Nuclear, Boston, Mass.) to give count rates of $10^{6} \mathrm{dpm} / \mathrm{ml}$. Unlabeled $\mathrm{RbCl}, 0.1 \mathrm{mM}$, was also present. After a further 30 -min incubation at $30^{\circ} \mathrm{C}$, the left atrial samples were removed, rinsed briefly in four consecutive beakers containing $300 \mathrm{ml}$ of cold physiologic media, and then placed in vials containing $1 \mathrm{ml}$ of media. Cerenkov radiation was measured with a Packard model 3385 scintillation counter at $4^{\circ} \mathrm{C}$ (Packard Instrument Co. Inc., Downers Grove, Ill.). The tissues were then immediately blotted and weighed. $\mathrm{Rb}^{+}$active transport was calculated as the difference in uptake in the presence and absence of ouabain, $1 \mathrm{mM}$, in nanomoles of $\mathrm{Rb}$ per milligram wet weight per $30 \mathrm{~min}$ $(18,19)$.

Myocardial norepinephrine assay. Left atrial and left ventricular norepinephrine content was kindly determined by Dr. Lewis Landsberg (Dept. of Medicine, Beth Israel Hospital and Harvard Medical School) by high performance liquid chromatography as previously described (20).

Statistical analysis. For statistical analysis of the data, Student's $\boldsymbol{t}$ test for unpaired observations was used; $\boldsymbol{P}$ values $<0.05$ were considered significant (21).

\section{RESULTS}

Validation of method: linearity of $\mathrm{Rb}^{+}$transport with time and tissue weight. Left atrial tissue obtained as described above was incubated at $30^{\circ} \mathrm{C}$ in physiologic media containing ${ }^{86} \mathrm{Rb}^{+}$for periods of $5-60$ min. Tissues were then rinsed and $\mathrm{Rb}^{+}$uptake was determined, expressed as nanomoles of $\mathrm{Rb}$ per milligram wet weight of tissue. The results of the time course of
$\mathrm{Rb}^{+}$uptake are shown in Fig. $1 A$. Rb ${ }^{+}$active transport (ouabain inhibitable transport) into guinea pig left atrial samples was linear for at least $30 \mathrm{~min}$. A slight
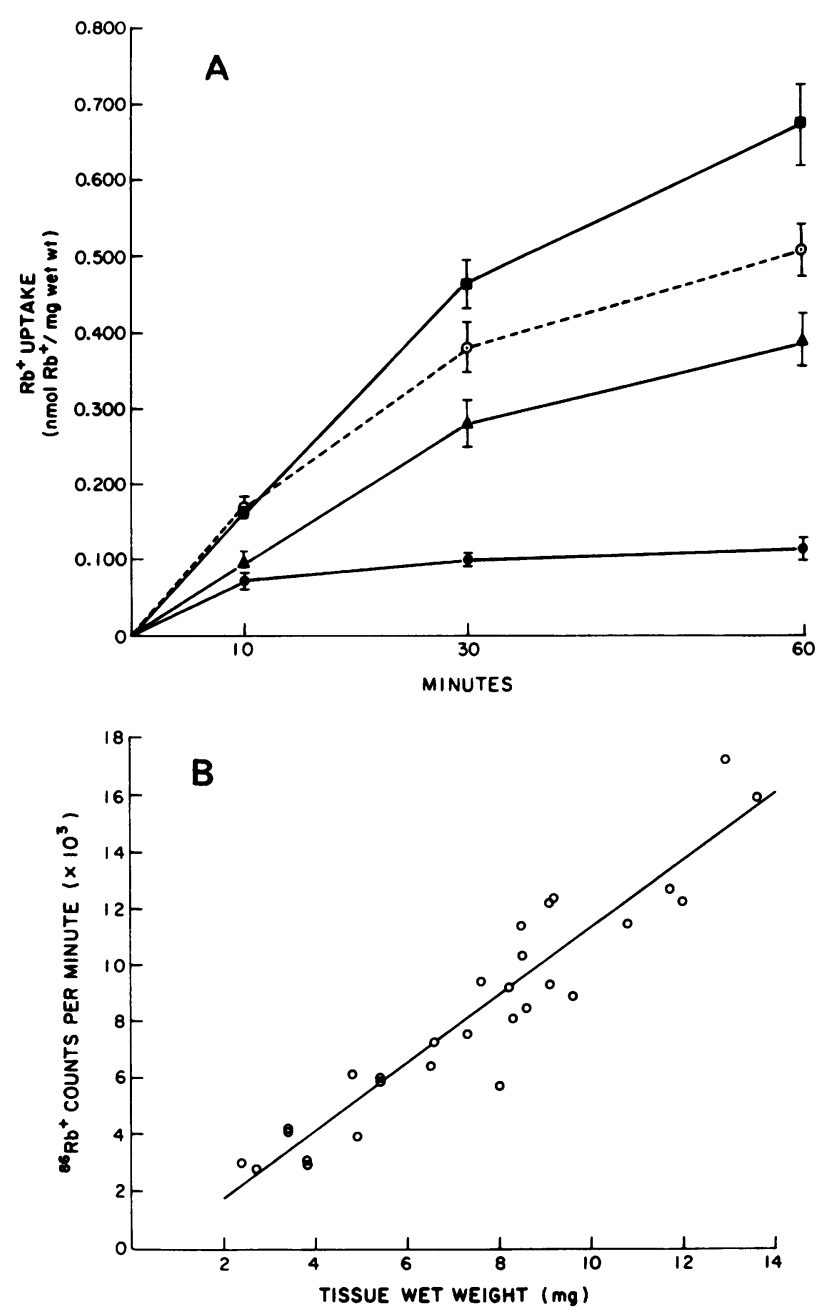

FigURE 1 (A) Time-course of $\mathbf{R b}^{+}$uptake by guinea pig left atria in vitro. Values are means \pm SEM. Left atria from a total of 15-20 animals were divided and pooled. 5-10 tissue samples were removed for study at each time point. The upper curve ( $\square$ ) shows total $\mathbf{R b}^{+}$uptake (plotted instead of ouabaininhibitable uptake to enhance legibility) in the presence of isoproterenol $10 \mathrm{nM}$. The next curve $(\odot)$ indicates total $\mathbf{R b}^{+}$ uptake in the absence of ouabain in untreated tissue. The next curve $(\Delta)$ represents $\mathrm{Rb}^{+}$active uptake (ouabain inhibitable uptake in untreated tissue). The lower curve (O) indicates $\mathrm{Rb}^{+}$uptake in the presence of ouabain, $1 \mathrm{mM}$ (passive uptake). Uptake of $\mathrm{Rb}^{+}$in the presence of both $1 \mathrm{mM}$ ouabain and $10 \mathrm{nM}$ isoproterenol was not different from uptake measured in the presence of $1 \mathrm{mM}$ ouabain alone (data not shown). (B) Effect of tissue weight on $\mathbf{R b}^{+}$transport into guinea pig left atria. Counts per minute (Cerenkov radiation) were measured over the weight range shown after a 60 -min incubation as described in Methods $\left({ }^{86} \mathrm{Rb}^{+}\right.$present for the final $30 \mathrm{~min}$ ). A linear correlation was observed $(r=0.944, P<0.001, n=29)$ between tissue wet weight and $\mathrm{Rb}^{+}$uptake. 
decrease in the rate of active transport was evident after longer incubation periods.

To determine the effect of individual tissue sample sizes on $\mathrm{Rb}^{+}$transport, samples were incubated in media for $30 \mathrm{~min}$, then in media containing ${ }^{86} \mathrm{Rb}^{+}$for an additional $30 \mathrm{~min}$. When the counts per minute of ${ }^{86} \mathrm{Rb}$ uptake were plotted against the wet weight of tissue, the results indicate, within the range of tissue weights used, a linear correlation $(r=0.944)$ between tissue wet weight and $\mathrm{Rb}^{+}$uptake (Fig. $1 B$ ).

Effects of low concentrations of ouabain on monovalent cation active transport. In this and subsequent experiments, the left atrial tissues were preincubated in physiologic media for $10 \mathrm{~min}$ at $30^{\circ} \mathrm{C}$, and then transferred to flasks containing the same media with or without additional agents for $30 \mathrm{~min}$ at $30^{\circ} \mathrm{C}$. The tissue samples were then transferred to flasks containing the same pharmacologic agents with the addition of ${ }^{86} \mathrm{Rb}^{+}$for a final 30 -min incubation at $30^{\circ} \mathrm{C}$, for a total incubation time with drugs of $60 \mathrm{~min}$.

The conditions for assessment of monovalent cation active transport by guinea pig left atria used in these experiments were similar to those employed by Ghysel-Burton and Godfraind (6), except that our tissue samples were quiescent. The low concentration of ouabain selected, $3 \mathrm{nM}$, was the concentration reported by Ghysel-Burton and Godfraind (6) to result in enhanced monovalent cation transport and increased intracellular $\mathrm{K}^{+}$concentrations $\left([\mathrm{K}]_{\mathrm{i}}\right)$ together with decreased $[\mathrm{Na}]_{\mathbf{i}}$.

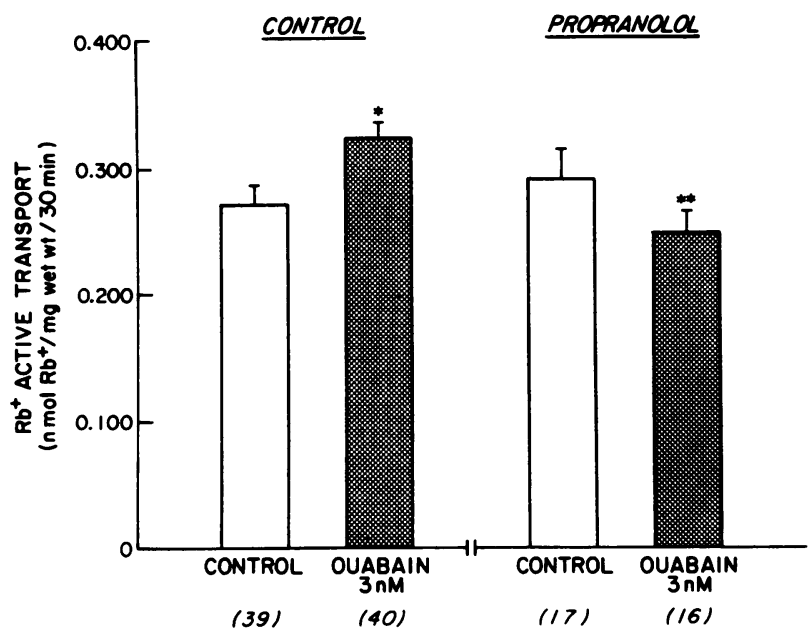

FIGURE 2 Effect of $3 \mathrm{nM}$ ouabain on $\mathrm{Rb}^{+}$active transport into guinea pig left atria. In the presence of $3 \mathrm{nM}$ ouabain $\mathrm{Rb}^{+}$ active transport was stimulated $20 \pm 8 \%$ above base-line values after a 60 -min incubation at $30^{\circ} \mathrm{C}$, (left panel). When left atrial tissue was preincubated in the presence of propranolol $1 \mu \mathrm{M}$ for $15 \mathrm{~min}$, and then in media containing both propranolol and $3 \mathrm{nM}$ ouabain for $60 \mathrm{~min}$, no stimulation of $\mathrm{Rb}^{+}$active transport occurred in response to $3 \mathrm{nM}$ ouabain (right panel). Numbers in parentheses indicate number of samples studied; vertical lines represent \pm 1 SEM. ${ }^{*} P<0.01 ;{ }^{* *} P$, NS.

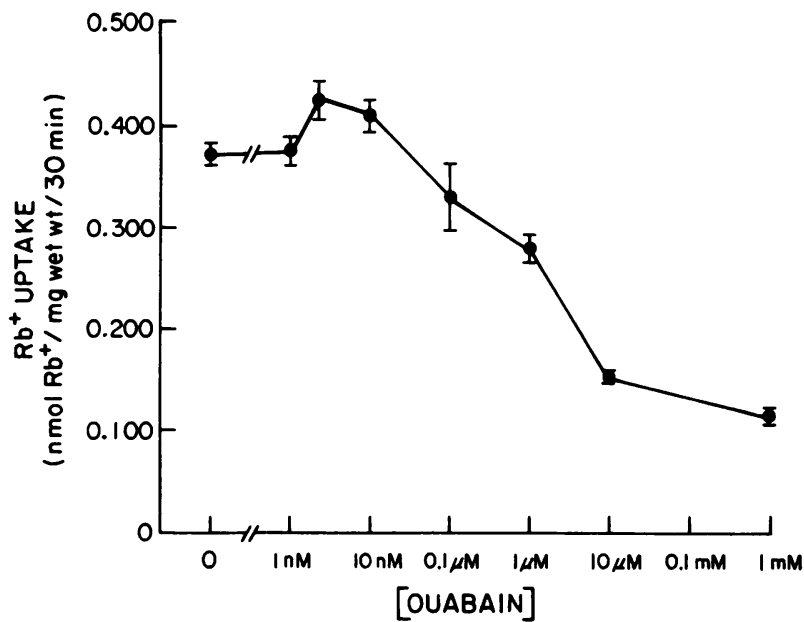

Figure 3 Effect of ouabain on $\mathrm{Rb}^{+}$uptake into guinea pig left atria. Values are mean $\pm S E M$ for 5-18 tissues at each point. Samples were incubated for $30 \mathrm{~min}$ in the presence of the indicated ouabain concentration and then in the presence of the same ouabain concentration and ${ }^{86} \mathrm{Rb}+$ for an additional 30 min as described in Methods. Significant $(P<0.05)$ stimulation of $\mathrm{Rb}^{+}$transport occurred at $3 \mathrm{nM}$ ouabain and inhibition was observed at ouabain concentrations of $\geq 0.10 \mu \mathrm{M}$ or greater.

When guinea pig left atrial samples were incubated in the presence of $3 \mathrm{nM}$ ouabain (Sigma Chemical Co., St. Louis, Mo.) active transport was stimulated $20 \pm 8 \%$ ( \pm SEM) $\left(0.272 \pm 0.015-0.326 \pm 0.011 \mathrm{nmol} \mathrm{Rb}^{+} / \mathrm{mg}\right.$ wet wt per $30 \mathrm{~min}, P<0.05$ ) above base-line values, as summarized in Fig. 2. These results are similar to the enhancement by $3 \mathrm{nM}$ ouabain found by GhyselBurton and Godfraind (6) for ${ }^{42} \mathrm{~K}^{+}$accumulation in guinea pig left atria.

In the experiment shown in Fig. 3, a range of concentrations of ouabain was used in the incubation media. Once again, a significant $13 \pm 7 \%(P<0.05)$ increase in total $\mathrm{Rb}^{+}$transport $(19 \pm 8 \%$ increase in active transport) above base-line values occurred in the presence of $3 \mathrm{nM}$ ouabain. An insignificant increase in $\mathrm{Rb}^{+}$transport $(5 \pm 5 \%)$ occurred at $10 \mathrm{nM}$. Ouabain concentrations of $0.1 \mu \mathrm{M}$ or greater resulted in inhibition of $\mathrm{Rb}^{+}$transport which became essentially complete at $1 \mathrm{mM}$. These results indicate that myocardial monovalent cation active transport is increased to a modest but significant extent in the presence of $3 \mathrm{nM}$ ouabain under these experimental conditions.

Effects of exogenous catecholamines. In spite of extensive work in peripheral tissues and brain, information on the effects of catecholamines on myocardial active transport of monovalent cations is quite limited (22). Accordingly, to study the effects of exogenous catecholamines on active transport in intact left atrial tissue, experiments were carried out using $\alpha$ - and $\beta$-adrenergic agonists and antagonists.

The effect of norepinephrine (Sigma Chemical Co.) 
on $\mathrm{Rb}^{+}$active transport was examined by the addition of $10 \mathrm{nM}$ norepinephrine to standard media. Samples were incubated for $60 \mathrm{~min}$ (the final $30 \mathrm{~min}$ with ${ }^{86} \mathrm{Rb}^{+}$) at $30^{\circ} \mathrm{C}$ with and without $1 \mathrm{mM}$ ouabain. Ascorbic acid, $0.1 \mathrm{mM}$, was added to prevent oxidation and was included in control media used for comparison.

Norepinephrine, $10 \mathrm{nM}$, increased $\mathrm{Rb}^{+}$active transport by $29 \pm 10 \%(P<0.02)$ above base-line values $\left(0.318 \pm 0.015-0.410 \pm 0.026 \mathrm{nmol} \mathrm{Rb}^{+} / \mathrm{mg}\right.$ wet wt per 30 min), as illustrated in Fig. 4. At the time of the norepinephrine study, a separate group of tissue samples was incubated in standard media containing $3 \mathrm{nM}$ ouabain; as indicated in Fig. 4, an $18 \pm 7 \%$ $(P<0.05)$ stimulation above base-line values resulted $(0.318 \pm 0.015-0.375 \pm 0.018 \mathrm{nmol} \mathrm{Rb} / \mathrm{mg}$ wet wt per $30 \mathrm{~min}$ ).

Since norepinephrine has both $\alpha$ - and $\beta$-adrenergic agonist properties, catecholamine effects on monovalent cation active transport were characterized further in experiments using $\alpha$ - and $\beta$-adrenergic agonist and antagonist compounds. To study the effects of a pure $\beta$-agonist on $\mathrm{Rb}^{+}$active transport in intact left atrial tissue, 1-isoproterenol (Sigma Chemical Co.) in a concentration of $10 \mathrm{nM}$ was used. Higher concentrations, $0.1 \mu \mathrm{M}$ or greater, were associated with spontaneous contractions. At $10 \mathrm{nM}$ isoproterenol, no contractions were seen under the conditions used on inspection under a dissecting microscope.

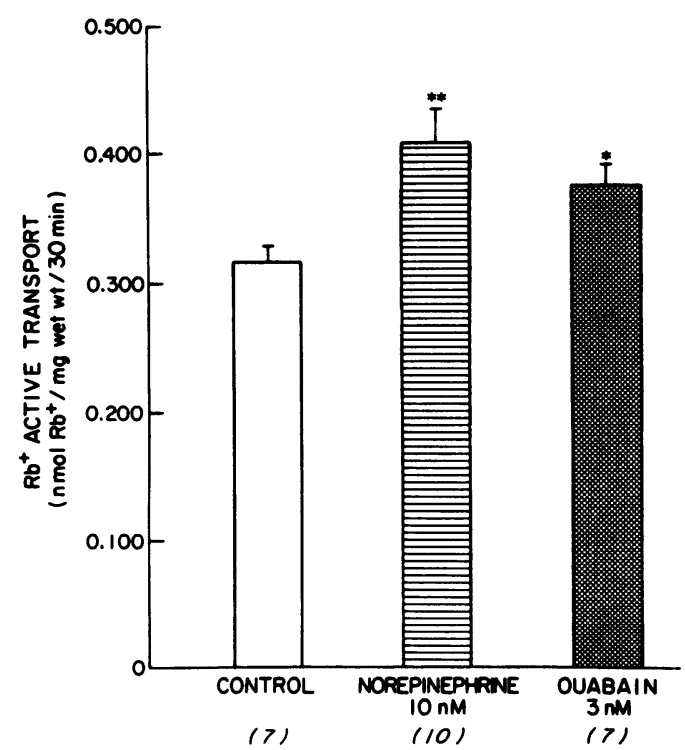

FIgURE 4 Norepinephrine-induced stimulation of $\mathrm{Rb}^{+}$active transport into guinea pig left atria. Norepinephrine $10 \mathrm{nM}$, increased $\mathrm{Rb}^{+}$active transport $29 \pm 10 \%$ over base-line values after a $60-\mathrm{min}$ incubation at $30^{\circ} \mathrm{C}$. A separate group of tissues was exposed to $3 \mathrm{nM}$ ouabain under the same conditions, and a small enhancement of $\mathrm{Rb}^{+}$active transport was again observed (18 $\pm 7 \%$ above base-line values). Values are means \pm 1 SEM for the number of tissue samples in parentheses. ${ }^{*} P<0.02 ;{ }^{* *}$ indicates $P<0.05$.
The effect of $10 \mathrm{nM}$ isoproterenol on $\mathrm{Rb}^{+}$active transport is shown in Fig. 5A. Isoproterenol stimulated $\mathrm{Rb}^{+}$active transport $33 \pm 10 \%(0.274 \pm 0.008-$ $0.364 \pm 0.025 \mathrm{nmol} \mathrm{Rb}^{+} / \mathrm{mg}$ wet wt per $30 \mathrm{~min} ; P<0.01$ ) above control values. When left atria were preincubated in $1 \mu \mathrm{M}$ propranolol for $15 \mathrm{~min}$, and then with both propranolol and isoproterenol for $60 \mathrm{~min}$, no stimulation of $\mathrm{Rb}^{+}$active transport was observed. These results indicated that isoproterenol enhancement of monovalent cation pump activity was mediated by a $\beta$-adrenergic mechanism.

The isoproterenol incubation was $60 \mathrm{~min}$, which raises the possibility that drug degradation may occur over this period even in the presence of ascorbic acid. In addition, because the response to isoproterenol in vivo is rapid, the possibility existed that more marked changes in $\mathrm{Rb}^{+}$active transport might occur before the single measurement made at $60 \mathrm{~min}$ or that transport might be nonlinear under these in vitro conditions. Fig. 1A shows the time-course of $\mathrm{Rb}^{+}$uptake in tissue incubated with $10 \mathrm{nM}$ isoproterenol, with and without $1 \mathrm{mM}$ ouabain. Isoproterenol-exposed tissues showed linear transport and higher values than controls at each time interval tested beyond $10 \mathrm{~min}$. Nonspecific or passive uptake, defined as uptake not inhibitable by $1 \mathrm{mM}$ ouabain, showed no change after the initial 10 min of incubation. ${ }^{86} \mathrm{Rb}^{+}$uptake in the presence of $1 \mathrm{mM}$ ouabain plus $10 \mathrm{nM}$ isoproterenol was identical to that measured in $1 \mathrm{mM}$ ouabain alone (Fig. 1A). Therefore $\mathrm{Rb}^{+}$transport was linear with time in both control and isoproterenol-treated left atrial tissue samples over the incubation period used in these experiments, and the stimulatory effect of isoproterenol on monovalent cation transport required an intact ouabain-sensitive pump mechanism.

Effect of $\beta$-adrenergic blockade on transport stimulation by $3 n M$ ouabain. If the hypothesis is correct that the stimulation of the Na-K pump by low concentrations of ouabain is mediated through the effects of endogenous catecholamines, pharmacologic blockade of catecholamine effects would be expected to abolish the stimulating effect. The role of $\beta$ adrenergic stimulation in the effect of low concentrations of ouabain on monovalent cation active transport was examined with the $\beta$-adrenergic antagonist propranolol. The effects of propranolol on the pumpstimulatory action of $3 \mathrm{nM}$ ouabain are illustrated on the right side of Fig. 2. When left atrial samples were preincubated in $1 \mu \mathrm{M}$ propranolol (Sigma Chemical Co.) for $15 \mathrm{~min}$, and then in media containing both propranolol and $3 \mathrm{nM}$ ouabain for $60 \mathrm{~min}\left({ }^{86} \mathrm{Rb}^{+}\right.$present for the final $30 \mathrm{~min}$ ), no stimulatory effect occurred in response to $3 \mathrm{nM}$ ouabain. To determine whether propranolol had any effect on monovalent cation active transport in the absence of added ouabain or adrenergic agents, concentrations of $10 \mathrm{nM}$ and $10 \mu \mathrm{M}$ were 
studied in comparison with control conditions. No significant differences were observed, which indicates that $1 \mu \mathrm{M}$ propranolol alone did not alter base-line active transport values. Thus, the responses to propranolol are also consistent with enhancement of $\mathrm{Na}-\mathrm{K}$ pump activity by $3 \mathrm{nM}$ ouabain via a mechanism requiring an intact $\beta$-adrenergic effector system.

Effect of $\alpha$-adrenergic agonists and antagonists. No influence of $\alpha$-adrenergic agonists on monovalent cation transport has been observed in skeletal muscle $(9,23,24)$. We addressed this issue in myocardium using the $\alpha$-adrenergic agonist phenylephrine. Phenylephrine, $1 \mu \mathrm{M}$ (Winthrop Laboratories, New York) was added to physiologic media together with 0.1 $\mathrm{mM}$ ascorbic acid to retard oxidation. The $\alpha$-adrenergic antagonist phentolamine (Ciba-Geigy Corp., Summit, $\mathrm{N}$. J.) in a concentration of $1 \mu \mathrm{M}$ was used alone or in combination with phenylephrine. When the combined effects of the $\alpha$-agonist and antagonist were studied, the tissues were preincubated for $15 \mathrm{~min}$ with phentolamine alone before exposure to both drugs.

There was no significant effect of phenylephrine on $\mathrm{Rb}^{+}$active transport $(0.276 \pm 0.007-0.253 \pm 0.014 \mathrm{nmol}$ $\mathrm{Rb}^{+} / \mathrm{mg}$ wet wt per $\left.30 \mathrm{~min} ; \boldsymbol{P}, \mathrm{NS}\right)$. Phentolamine also did not significantly change $\mathrm{Rb}^{+}$active transport $(0.276 \pm 0.007-0.296 \pm 0.012 \mathrm{nmol} \mathrm{Rb}+/ \mathrm{mg}$ wet wt per 30 min, $P, N S)$. The combination of both the agonist and antagonist produced no significant change in $\mathrm{Rb}^{+}$active transport $\left(0.276 \pm 0.007-0.311 \pm 0.023 \mathrm{nmol} \mathrm{Rb}^{+} / \mathrm{mg}\right.$ wt per $30 \mathrm{~min}, P, \mathrm{NS})$. These findings indicate that under the conditions of our experiments, $\alpha$-adrenergic mechanisms are not involved in modulation of monovalent cation active transport.

Effect of endogenous catecholamines on monovalent cation active transport. The effect of releasing endogenous stores of myocardial catecholamines was studied by exposing tissue in vitro to the primary phenolic amine tyramine. Tyramine, $0.1 \mu \mathrm{M}$ (Sigma Chemical Co.) was added to incubation media together with $1 \mathrm{mM}$ ascorbic acid to retard oxidation. Tyramine stimulated $\mathrm{Rb}^{+}$active transport $26 \pm 12 \%(0.282 \pm 0.018-$ $0.354 \pm 0.024 \mathrm{nmol} \mathrm{Rb}^{+} / \mathrm{mg}$ wet wt per $30 \mathrm{~min} ; P<0.05$ ) above base-line values. These results are consonant with the exogenous catecholamine experiments and demonstrate that myocardial monovalent cation active transport is enhanced by either endogenous or exogenous catecholamines. This result is consistent with the postulated stimulation of the Na-K pump by low concentrations of ouabain through enhancement of endogenous myocardial catecholamine effects.

Catecholamine depletion studies. To examine further the role of catecholamines in mediating sodium pump stimulation by low concentrations of ouabain, depletion of myocardial catecholamines was performed in vivo. Using a protocol similar to that of Furchgott et al. (25), guinea pigs received a single dose of
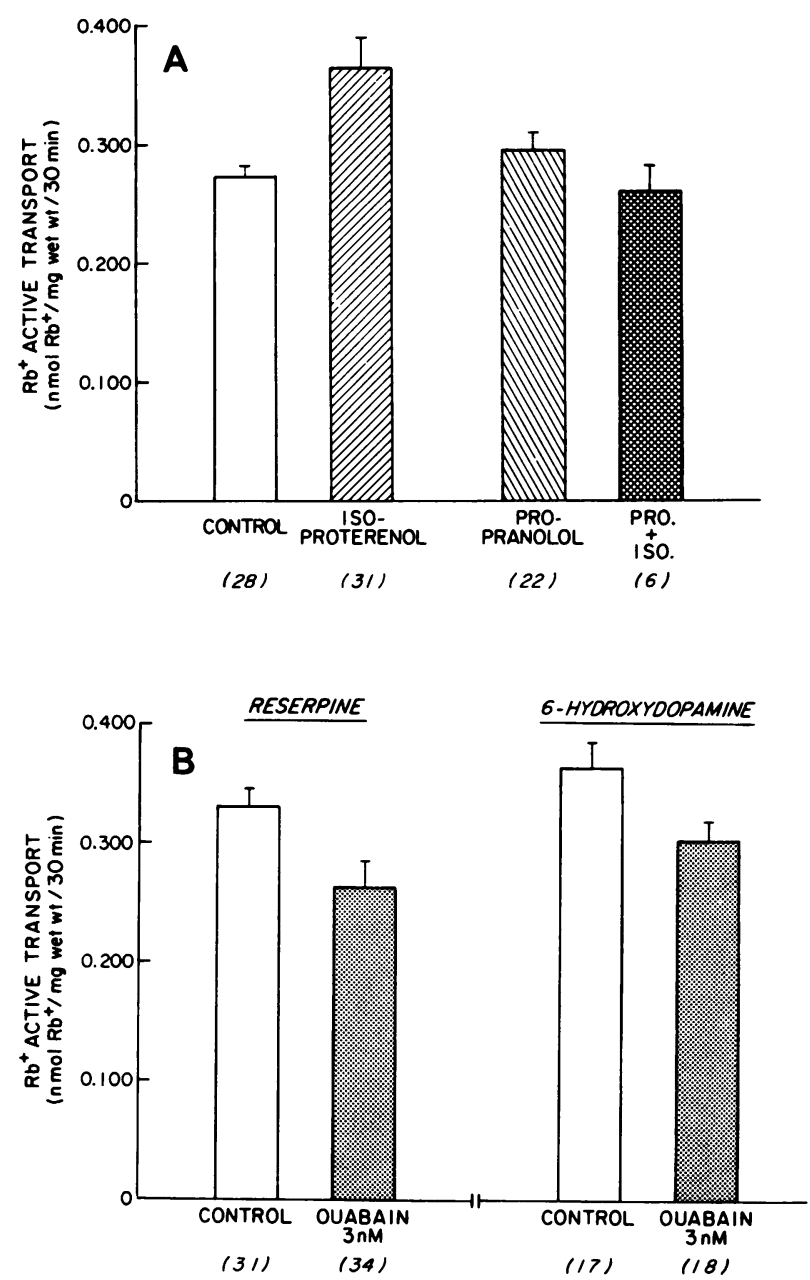

FIGURE 5 (A) The effects of isoproterenol and propranolol on $\mathrm{Rb}^{+}$active transport in guinea pig left atria. After a $60 \mathrm{~min}$ incubation at $30^{\circ} \mathrm{C}$ in the presence of isoproterenol, $10 \mathrm{nM}$, $\mathrm{Rb}^{+}$active transport was increased $33 \pm 10 \%$ above base-line values $(P<0.01)$. When tissues were preincubated for $15 \mathrm{~min}$ in propranolol, $1 \mu \mathrm{M}$, and then in both propranolol and isoproterenol, no stimulation of $\mathrm{Rb}^{+}$transport occurred. (B) The effect of in vivo catecholamine depletion on $\mathrm{Rb}^{+}$active transport in guinea pig left atria. Left atria from reserpinetreated guinea pigs were incubated for $60 \mathrm{~min}$ at $30^{\circ} \mathrm{C}$ in the presence or absence of $3 \mathrm{nM}$ ouabain. No ouabain-induced enhancement of $\mathrm{Rb}^{+}$active transport occurred; rather, a small inhibition $(80 \pm 8 \%$ of base-line values, $P<0.05)$ was observed (left panel). A similar small inhibition ( $83 \pm 7 \%$ of base-line values, $P<0.05$ ) in $\mathrm{Rb}^{+}$active transport was measured in left atrial tissue removed from animals treated with 6-OHDA (right panel). Values shown are means \pm 1 SEM for the numbers of tissue samples indicated in parentheses. iso., isoproterenol; pro., propranolol.

reserpine (Ciba-Geigy Corp.), $5 \mathrm{mg} / \mathrm{kg}$ i.p., and were used for study $24 \mathrm{~h}$ later. A control group received a single injection of normal saline of equivalent volume.

A second method of catecholamine depletion was also used. 6-Hydroxydopamine (6-OHDA) (Sigma Chemical Co.) is known to induce a marked depletion 
of catecholamines in various sympathetically innervated organs by destroying adrenergic nerve terminals (26). In the present study, 6-OHDA was dissolved in normal saline and ascorbic acid, $1 \mathrm{mM}$, immediately before use and was administered in three doses, $12 \mathrm{~h}$ apart. Each dose was $50 \mathrm{mg} / \mathrm{kg}$ i.p. Animals were used $12 \mathrm{~h}$ after the last injection. Controls were treated with saline injections of equal volume according to the same schedule. Norepinephrine content in the left atria and left ventricles from three animals in each group were measured. The results are summarized in Table I. Reserpine reduced both left atrial and left ventricular norepinephrine content to $\leq 2 \%$ of control values, comparable to levels reported by Furchgott et al. (25). Myocardial norepinephrine levels were reduced by $6-$ OHDA to $\sim 7 \%$ of control values (Table I), a reduction that agrees closely with that reported by Thoenen and Tranzer (26).

The responses of left atrial monovalent cation active transport to $3 \mathrm{nM}$ ouabain in tissue samples from animals given reserpine or 6-OHDA are illustrated in Figure 5B. Left atrial samples from reserpine-treated guinea pigs failed to show any stimulation when exposed to $3 \mathrm{nM}$ ouabain. On the contrary, a small but significant inhibition of $\mathrm{Rb}^{+}$active transport was observed $(80 \pm 8 \%$ of control, $P<0.02)$. In a similar fashion, left atria from 6-OHDA-treated animals showed no enhancement of $\mathrm{Rb}^{+}$active transport when exposed to this low concentration of ouabain (Fig. 5B). Rather, inhibition of transport to $83 \pm 7 \%(P<0.05)$ of control values occurred. The results from the catecholamine-depleted tissue studies indicate that the mechanism underlying stimulation of myocardial monovalent cation active transport by low concentrations of ouabain requires catecholamines to be present in amounts greater than those that remain after in vivo exposure to relatively large doses of reserpine or 6-OHDA. Base-line $\mathrm{Rb}^{+}$transport values after reserpine- or 6-OHDA-induced catecholamine depletion tended to be greater than values from normal animals, a finding for which we have no ready explanation.

\section{DISCUSSION}

An extensive literature documents the fact that cardiac glycosides inhibit NaK-ATPase activity and the active transport of $\mathrm{Na}^{+}$and $\mathrm{K}^{+}$across cell membranes $(2,3)$. These effects are manifest at concentrations causing toxicity (usually manifest as rhythm disturbances and/or contracture) in intact tissue and, in some studies, at positively inotropic but subtoxic ("therapeutic") concentrations $(1,27,28)$.

As stated previously, prior studies suggest that catecholamine stimulation of active $\mathrm{Na}^{+}$and $\mathrm{K}^{+}$transport is mediated through a $\beta$-adrenergic mechanism in rat brain $(10,11,29)$, skeletal muscle $(9,12,30)$, and turkey erythrocytes (31). Our results in guinea pig left atrial preparations are similar since stimulation of $\mathbf{R b}^{+}$ active transport occurred in response to the addition of isoproterenol or norepinephrine and when endogenous catecholamines were released by tyramine. Furthermore, the stimulatory response to isoproterenol was blocked completely by propranolol.

Paton (32), Seifen (14), Lindmar and Löffelholz (33), and Harvey (15) have provided evidence that ouabain in concentrations of $0.1 \mu \mathrm{M}$ to $0.1 \mathrm{mM}$ alters myocardial norepinephrine content by increasing release, blocking reuptake, or both, and that at least the chronotropic effects of ouabain are related in part to this catecholamine response (14). In adrenergic components of dog vascular tissue (34) or guinea pig heart (22), ouabain $(0.1 \mathrm{nM}$ to $1 \mu \mathrm{M})$ stimulates displacement of norepinephrine from neuronal stores (34) or increases $\mathrm{Na}^{+}$-dependent transport of norepinephrine (22). Although we did not measure the effects of low ouabain concentrations on myocardial norepinephrine turnover or content, our finding that $3 \mathrm{nM}$ ouabain is without a stimulatory effect on the $\mathrm{Na}-\mathrm{K}$ pump in norepinephrinedepleted tissue suggests that the presence of endogenous catecholamines is necessary for the mediation of pump stimulation by ouabain. As noted earlier, myocardial tissues depleted of norepinephrine, by treatment with either reserpine or 6-OHDA, maintained substantial levels of ouabain inhibitable monovalent cation active transport, which suggests that under these conditions maintenance of base-line or somewhat above base-line levels of monovalent cation active transport does not require the presence of functional adrenergic nerve terminals. It is of particular interest that inhibition of $\mathrm{Rb}^{+}$transport, rather than stimulation, was elicited by $3 \mathrm{nM}$ ouabain after depletion of endogenous catecholamine stores.

TABLE I

Norepinephrine Content in Guinea Pig Myocardium

\begin{tabular}{lccc}
\hline \multicolumn{1}{c}{ Tissue } & Control & Reserpine & 6-OHDA \\
\hline & & $n g / m g$ wet $w t^{*}$ \\
Left atrium $(n=3)$ & $3.109 \pm 0.357$ & $0.062 \pm 0.016$ & $0.241 \pm 0.015$ \\
Left ventricle $(n=3)$ & $1.645 \pm 0.158$ & $0.025 \pm 0.002$ & $0.118 \pm 0.015$ \\
\hline
\end{tabular}

* Values are given as means $\pm \mathrm{SEM}$; conditions are as described in Methods. 
The mechanism of action of therapeutic concentrations of cardiac glycosides, recently reviewed by Noble (28), is controversial since the relationship between the increased force of contraction attributed to low concentrations of cardiac glycosides has been associated with $\mathrm{Na}-\mathrm{K}$ pump stimulation in some studies (4-6) and with inhibition in others $(18,19,27,35)$. Some workers have reported stimulation of brain NaK-ATPase by low ouabain concentrations (36), or alterations in myocardial $[\mathrm{K}]_{1}$ and $[\mathrm{Na}]_{1}$, which suggested enhanced $\mathrm{Na}-\mathrm{K}$ pump action $(6,8)$. The last two studies were of particular interest since small but significant increases in contractility were observed. To explain these results, Godfraind and Ghysel-Burton (7), like Palmer et al. (36), favored the existence of two specific ouabain receptors: a high-affinity site related to Na-K pump stimulation, and a low-affinity site associated with Na-K pump inhibition (7).

Stimulation of partially purified myocardial NaKATPase has not generally been observed at low ouabain concentrations sufficient to cause a threshold positive inotropic effect $(27,35)$. Using a stable intact dog preparation, we found that at clinically relevant plasma concentrations of ouabain or digoxin in the 1-10 $\mathrm{nM}$ range, inhibition of active transport of $\mathrm{Rb}^{+}$into myocardial biopsy samples was observed at the onset and during sustained enhanced contractility $(18,19,37)$. As noted by Noble (28) the concentration of $\mathrm{K}^{+}(2.0 \mathrm{mM})$ used in the transport assay media in our earlier studies might have shifted the threshold for inhibition of active transport of cardiac glycosides to the left, i.e., into the inhibition range, but our more recent experiments, which used a $\mathrm{K}^{+}$concentration of $4.0 \mathrm{mM}$ in transport assay media, still show significant inhibition of both myocardial and Purkinje fiber monovalent cation transport at a mean steady-state plasma digoxin concentration of $2.7 \mathrm{nM}$ (2.1 ng/ml) (37). Our studies of ouabain-induced inotropic effects in cultured chick embryo heart cells (devoid of adrenergic input) show enhanced contractility only at ouabain concentrations causing significant inhibition of monovalent cation active transport, accompanied by increased intracellular contents of sodium and rapidly exchangeable calcium (38). These findings are supported by Eisner and Lederer (39), who concluded that inotropic effects of glycosides in sheep Purkinje preparations are invariably associated with measurable $\mathrm{Na}-\mathrm{K}$ pump inhibition. To reconcile these latter findings with studies reporting increased force of contraction together with $\mathrm{Na}-\mathrm{K}$ pump stimulation, Noble (28) has suggested a membrane effect at low glycoside concentrations that initiates mechanisms leading to both pump stimulation and enhanced contractility. The catecholamine-mediated stimulation of monovalent cation transport in response to $3 \mathrm{nM}$ ouabain described in this report fits this hypothesis. The possibility that contractile effects on intact myocardium of ouabain concentrations in the $\mathrm{nM}$ range are catecholamine-mediated deserves further study.

In conclusion, we have confirmed earlier reports that low ouabain concentrations in the nanomolar range stimulate monovalent cation active transport in guinea pig left atria, and we have demonstrated here that this effect is blocked by propranolol. Exogenous and endogenous activators of $\beta$-adrenergic (but not $\alpha$ adrenergic) mechanisms also stimulate myocardial active transport to a similar extent, and these effects are blocked by propranolol. When guinea pig left atria are depleted of norepinephrine in vivo, $3 \mathrm{nM}$ ouabain fails to enhance $\mathrm{Rb}^{+}$active transport, but is rather associated with significant inhibition of active transport. On the basis of the data presented here, we conclude that the stimulatory effect of low ouabain concentrations on the Na-K pump is mediated, at least in part, by $\beta$-adrenergic effects of endogenous catecholamines.

\section{ACKNOWLEDGMENTS}

We thank Dr. Lewis Landsberg, Dept. of Medicine, Beth Israel Hospital and Harvard Medical School, for determining the myocardial norepinephrine levels. The expert secretarial assistance of Barbara Cesaro is gratefully acknowledged.

This work was supported in part by grants HL-18003 and HL-24302 from the National Institutes of Health, and by the Charles H. Hood Foundation.

\section{REFERENCES}

1. Repke, K. 1963. Influence of cardioactive principles on pump ATPase. In Proceedings of the First International Pharmacological Meeting, Stockholm, vol. III. New Aspects of Cardiac Glycosides. W. Wilbrandt and P. Lindgren, editors. Pergamon Press, Oxford. 65-73.

2. Akera, T., and T. M. Brody. 1977. The role of $\mathrm{Na}^{+}$ $\mathrm{K}^{+}$-ATPase in the inotropic action of digitalis. Pharmacol. Rev. 29: 187-220.

3. Schwartz, A., G. E. Lindenmayer, and J. C. Allen. 1975. The sodium-potassium adenosine triphosphatase: pharmacological, physiological and biochemical aspects. Pharmacol. Rev. 27: 3-134.

4. Blood, B. E., and D. Noble. 1978. Two mechanisms for the inotropic action of ouabain on sheep cardiac Purkinje fiber contractility. In Biophysical Aspects of Cardiac Muscle. M. Morad and M. Tabatabai, editors. Academic Press, Inc., New York. 369-379.

5. Cohen, I., J. Daut, and D. Noble. 1976. An analysis of the actions of low concentrations of ouabain on membrane currents in Purkinje fibers. J. Physiol. (Lond.). 260: 75-103.

6. Ghysel-Burton, J., and T. Godfraind. 1979. Stimulation and inhibition of the sodium pump by cardioactive steroids in relation to their binding sites and their inotropic effect on guinea-pig isolated atria. $\mathrm{Br}$. J. Pharmacol. 66: 175-184.

7. Godfraind, T., and J. Ghysel-Burton. 1977. Binding sites related to ouabain-induced stimulation or inhibition of the sodium pump. Nature (Lond.). 265: 165-166. 
8. Noach, E., J. Felgenträger, and B. Zettner. 1979. Changes in myocardial $\mathrm{Na}$ and $\mathrm{K}$ content during the development of cardiac glycoside inotropy. J. Mol. Cell. Cardiol. 11: 1189-1194.

9. Rogus, E. M., L. C. Cheng, and K. Zierler. 1977. $\beta$ adrenergic effect on $\mathrm{Na}^{+}-\mathrm{K}^{+}$transport in rat skeletal muscle. Biochim. Biophys. Acta. 464: 347-355.

10. van der Krogt, J. A., and R. D. M. Belfroid. 1980. Characterization and localization of catecholaminesusceptible Na-K ATPase activity of rat striatum: studies using catecholamine receptor (ant) agonists and lesion techniques. Biochem. Pharmacol. 29: 857-868.

11. Wu, P. H., and J. W. Phillis. 1978. Effects of $\alpha$ - and $\beta$-adrenergic blocking agents on the biogenic amine stimulated $\left(\mathrm{Na}^{+}-\mathrm{K}^{+}\right)$ATPase of rat cerebral cortical synaptosomal membrane. Gen. Pharmacol. 9: 421-424.

12. Cheng, L. C., E. M. Rogus, and K. Zierler. 1977. Catechol, a structural requirement for $\left(\mathrm{Na}^{+}+\mathrm{K}^{+}\right)$ATPase stimulation in rat skeletal muscle membrane. Biochim. Biophys. Acta. 464: 338-346.

13. Sharma, V. K., and S. P. Banerjee. 1979. Regeneration of $\left[{ }^{3} \mathrm{H}\right]$ ouabain binding to $\left(\mathrm{Na}^{+}+\mathrm{K}^{+}\right)$-ATPase in chemically sympathectomized cat peripheral organs. Mol. Pharmacol. 15: 35-42.

14. Seifen, E. 1974. Evidence for participation of cateamines in cardiac action of ouabain. Eur. J. Pharmacol. 26: $115-118$.

15. Harvey, S. C. 1975. The effects of ouabain and phenytoin on myocardial norepinephrine. Arch. Int. Pharmacodyn. Ther. 213: 222-234.

16. Levi, G., P. J. Roberts, and M. Raiteri. 1976. Release and exchange of neurotransmitters in synaptosomes: effects of the ionophore A 23187 and of ouabain. Neurochem. Res. 1: 409-416.

17. Garcia, A. G., and S. M. Kirpekar. 1973. Release of noradrenaline from slices of cat spleen by pretreatment with calcium, strontium, and barium. J. Physiol. (Lond.). 235: 693-713.

18. Hougen, T. J., and T. W. Smith. 1978. Inhibition of myocardial monovalent cation active transport by subtoxic doses of ouabain in the dog. Circ. Res. 42: 856-863.

19. Hougen, T. J., B. L. Lloyd, and T. W. Smith. 1979. Effects of inotropic and arrhythmogenic digoxin doses and of digoxin-specific antibody on myocardial monovalent cation transport in the dog. Circ. Res. 44: 23-31.

20. Hallman, H., L-O. Farnebo, B. Hamberger, and G. Jonsson. 1976. A sensitive method for the determination of plasma catecholamines using liquid chromatography with electrochemical detection. Life Sci. 23: 1049-1052.

21. Snedecor, G. W., and W. G. Cochran. 1967. Statistical Methods. Iowa State University Press, Ames, Iowa. 6 th ed.

22. Sharma, V. K., and S. P. Banerjee. 1980. Ouabain stimulation of noradrenaline transport in guinea pig heart. Nature (Lond.). 286: 817-819.

23. Clausen, T., and J. A. Flatman. 1977. The effect of catecholamines on $\mathrm{Na}-\mathrm{K}$ transport and membrane potential in rat soleus muscle. J. Physiol. (Lond.). 270: 383-414.

24. Clausen, T., and J. A. Flatman. 1980. $\beta$-adrenoceptors mediate the stimulating effect of adrenaline on active electrogenic Na-K transport in rat soleus muscle. $B r . J$. Pharmacol. 68: 749-755.

25. Furchgott, R. F., S. M. Kirpekar, M. Rieker, and A. Schwab. 1963. Actions and interactions of norepinephrine, tyramine, and cocaine on aortic strips of rabbit and left atria of guinea pig and cat. J. Pharmacol. Exp. Ther. 142: $39-58$.

26. Thoenen, H., and J. P. Tranzer. 1968. Chemical sympathectomy by selective destruction of adrenergic nerve endings with 6-hydroxydopamine. NaunynSchmiedebergs Arch Pharmak. Exp. Pathol. 261: 271-288.

27. Schwartz, A., J. C. Allen, W. B. Van Winkle, and R Munson. 1974. Further studies on the correlation between the inotropic action of ouabain and its interaction with the $\mathrm{Na}^{+}, \mathrm{K}^{+}$-adenosine triphosphatase: isolated perfused rabbit and cat hearts. J. Pharmacol. Exp. Ther. 919: 119-127.

28. Noble, D. 1980. Mechanism of action of therapeutic levels of cardiac glycosides. Cardiovasc. Res. 14: 495-514.

29. Wu, P. H., and J. W. Phillis. 1980. Characterization of receptor-mediated catecholamine activation of rat brain cortical $\mathrm{Na}^{+}-\mathrm{K}^{+}$-ATPase. Int. J. Biochem. 12: 353-359.

30. Bowman, W. C. 1981. Effects of adrenergic activators and inhibitors on skeletal muscle. In Handbook of Experimental Pharmacology. L. Szekeres, editor. SpringerVerlag, Berlin, Vol. 54, Part II: 47-128.

31. Gardner, J. D., H. L. Klaeveman, J. P. Bilezikian, and G. D. Aurbach. 1974. Effects of ouabain on catecholamine stimulated sodium transport in turkey erythrocytes. J. Biol. Chem. 249: 516-520.

32. Paton, D. M. 1973. Mechanism of efflux of noradrenaline from adrenergic nerves in rabbit atria. Br. J. Pharmacol. 49: 614-627.

33. Lindmar, R., and K. Löffelholz. 1974. The neuronal efflux of noradrenaline: dependency on sodium and facilitation by ouabain. Naunyn-Schmiedebergs Arch. Pharmacol. 284: $93-100$.

34. Lorenz, R. R., D. A. Powis, P. M. Vanhoutte, and J. T. Shepherd. 1980. The effects of acetylstrophanthidin and ouabain on the sympathetic adrenergic neuroeffector junction in canine vascular smooth muscle. Circ. Res. 47: 845-854.

35. Michael, L., B. J. R. Pitts, and A. Schwartz. 1978. Is pump stimulation associated with positive inotropy of the heart? Science (Wash. D. C.). 200: 1287-1289.

36. Palmer, R. F., K. C. Lasseter, and S. L. Melvin. 1966. Stimulation of $\mathrm{Na}^{+}$- and $\mathrm{K}^{+}$-dependent adenosine triphosphatase by ouabain. Arch. Biochem. Biophys. 113: 629-633.

37. Somberg, J. C., W. H. Barry, and T. W. Smith. 1981. Differing sensitivites of Purkinje fibers and myocardium to inhibition of monovalent cation transport by digitalis. J. Clin. Invest. 67: 116-123.

38. Biedert, S., W. H. Barry, and T. W. Smith. 1979. Inotropic effects and changes in sodium and calcium contents associated with inhibition of monovalent cation active transport by ouabain in cultured myocardial cells. J. Gen. Physiol. 74: 479-494.

39. Eisner, D. A., and W. J. Lederer. 1980. The relationship between sodium pump activity and twitch tension in cardiac Purkinje fibers. J. Physiol. (Lond.). 303: 475-494. 